\title{
Gender violence perpetrated against trans women
}

\author{
A violência de gênero perpetrada contra mulheres trans \\ La violencia de género perpetrada contra mujeres trans
}

Izabel Cristina Brito da Silva' ORCID: 0000-0002-7411-3564

Ednaldo Cavalcante de Araújo' ORCID: 0000-0002-1834-4544

Alef Diogo da Silva Santana" ORCID: 0000-0001-8165-6412

Jefferson Wildes da Silva Moura' ORCID: 0000-0002-7192-1099

Marclineide Nóbrega de Andrade Ramalho' ORCID: 0000-0002-1911-6017

Paula Daniella de Abreu" ORCID: 0000-0001-8756-8173

'Universidade Federal de Pernambuco. Recife, Pernambuco, Brazil. "Universidade de São Paulo. Ribeirão Preto, São Paulo, Brazil.

How to cite this article: Silva ICB, Araújo EC, Santana ADS, Moura JWS, Ramalho MNA Abreu PD. Gender violence perpetrated against trans women. Rev Bras Enferm. 2022;75(Suppl 2):e20210173. https://doi.org/10.1590/0034-7167-2021-0173

Corresponding author:

Izabel Cristina Brito da Silva

E-mail: izabel.cristinabrito@ufpe.br

EDITOR IN CHIEF: Antonio José de Almeida Filho ASSOCIATE EDITOR: Maria Itayra Padilha

Submission: 03-06-2021

Approval: 06-08-2021

\begin{abstract}
Objectives: to identify scientific evidence on gender violence perpetrated against trans women. Methods: integrative review, carried out in June 2020, without time frame, in the Scopus, MEDLINE, Embase, CINAHL, WoS, Psyclnfo and LILACS databases. The controlled descriptors of DeCS, MeSH and their entry terms were used:"Transgender People,",Transgender","Gender

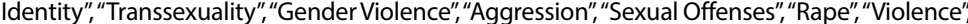
"Domestic Violence". The presentation and synthesis of the results were presented in the PRISMA-2009 flowchart. Results: the final sample, consisting of 16 articles, identified different types of violence (sexual, physical, verbal, psychological and financial), perpetrated by family members, strangers, police officers, intimate partners, health professionals, acquaintances, or friends. Conclusions: trans women suffer violence and social exclusion that result from stigma and discrimination due to gender identity and result in unrestricted damage to physical health Descriptors: Transgender Persons; Gender Identity; Gender-Based Violence;Violence; Nursing
\end{abstract}

\section{RESUMO}

Objetivos: identificar evidências científicas sobre as violências de gênero perpetradas contra mulheres trans. Métodos: revisão integrativa, realizada em junho de 2020, sem recorte temporal, nas bases de dados SCOPUS, Medline, Embase, CINAHL, WoS, Psyclnfo e LILACS. Foram utilizados os descritores controlados do DeCS, do MeSH e seus entry terms: "Pessoas Transgênero", "Transgêneros", "Identidade de Gênero", "Transexualidade", "Violência de Gênero", "Agressão", "Delitos Sexuais", “Estupro", "Violência”, "Violência Doméstica”. A apresentação e a síntese dos resultados foram apresentadas no fluxograma PRISMA-2009. Resultados: a amostra final, composta por 16 artigos, identificou violências de gênero diversas: sexual, física, verbal, psicológica e financeira perpetrada por familiares, desconhecidos, policiais, parceiros íntimos, profissionais da saúde, conhecidos ou amigos. Conclusões: a mulher trans sofre violências e exclusões sociais decorrentes de estigmas e discriminações pela identidade de gênero que resultam em danos à saúde além da física.

Descritores: Pessoas Transgênero; Identidade de Gênero; Violência de Gênero; Violência; Enfermagem.

\section{RESUMEN}

Objetivos: identificar evidencias científicas acerca de las violencias de género perpetradas contra mujeres trans. Métodos: revisión integrativa, realizada en junio de 2020, sin recorte temporal, en las bases de datos Scopus, MEDLINE, Embase, CINAHL, WoS, PsycInfo y LILACS. Fueron utilizados los descriptores controlados del DeCS, del MeSH y sus entry terms: "Personas Transgénero", “'Transgéneros", "Identidad de Género", "Transexualidad", "Violencia de Género", "Agresión”, “'Delitos Sexuales", “Estupro,, “Violencia”,"Violencia Doméstica”. La presentación y la síntesis de los resultados fueron presentadas en el flujograma PRISMA-2009. Resultados: la muestra final, compuesta por 16 artículos, identificó violencias de género diversas (sexual, física, verbal, psicológica y financiera), perpetradas por familiares, desconocidos, policiales, parceros íntimos, profesionales de salud, conocidos o amigos. Conclusiones: la mujer trans sufre violencias y exclusiones sociales que transcurren de estigmas y discriminaciones por la identidad de género y resultan en daños no restrictos a salud física.

Descriptores: Personas Transgénero; Identidad de Género; Violencia de Género; Violencia; Enfermería. 


\section{INTRODUCTION}

"Gender" is defined as a set of imposed sociocultural behaviors, delimited by the binary logic to define what it means to be a man or a woman ${ }^{(1)}$. This definition makes self-perception about oneself difficult, which is subjective and dynamic. Gender identity brings together a set of values, motivations and experiences learned throughout life that legitimizes other ways of being. People who identify themselves in the patterns of appearance and behavior culturally imposed on biological sex are called cisgender or cis men or women, whose gender identity and expression correspond to $\operatorname{sex}^{(1-3)}$. The linearity between body-sex-gender in Western society means that transgender or trans people do not identify with the gender assigned at birth, legitimized through anatomical sexual characteristics. Thus, transgender women do not recognize themselves in the male gender designated at birth, but, throughout life, they recognize themselves in the female gender as transsexual or transvestite women ${ }^{(2-3)}$.

Transgender women are often faced with discriminatory actions in society that stem from stigmas arising from a history of pathologizing their identity by medical science ${ }^{(3)}$. When seeking to carry out hormones or even surgical procedures in order to have a female body image, they are faced with the lack of preparation and lack of awareness of professionals in health services to welcome and meet these needs. Such a situation can result in abusive treatment, negligence and culminate in conditions harmful to mental, physical and sexual health ${ }^{(4-5)}$.

Cisgender or transgender women are more likely to suffer violence at any time in their lives because they are women ${ }^{(6)}$. Gender violence becomes more serious for those who have precarious socioeconomic conditions, who abuse psychoactive substances and who are sex workers, as they are more exposed to the historical processes that make them vulnerable ${ }^{(7)}$.

Furthermore, it is noteworthy that gender violence involves three social structures - patriarchy, machismo and capitalism - which act insidiously and operate through logics that will hierarchize bodies and lives ${ }^{(8)}$. The power relations that permeate society and families, and that make use of the inferiorization of the female gender through the supremacy of patriarchy, feed the gender violence reproduced against trans women. This violence can result in murder, rape, physical, verbal, psychological, sexual aggression, coercion, attacks in public or private environments, discrimination in formal workplaces, health services and educational institutions ${ }^{(9)}$.

Gender violence perpetrated against trans women in health services sometimes occurs through the reproduction of a binary and discriminatory care practice, immersed in a structure of oppression called institutionalized transphobia. Such situations contribute to assistance that is dissonant to the health needs of trans women, as well as to the disregard of their specificities and favoring the non-search for health care $^{(9)}$.

According to the National Comprehensive Health Policy for Lesbians, Gays, Bisexuals, Transvestites and Transsexuals, comprehensive health care for these people in the Unified Health System (SUS) recognizes that stigma, discrimination, domestic, sexual and social violence they cause illness and need strategies for coping and care in an intra- and inter-sectorial way, as stated in the guidelines and attributions brought by the policy within the scope of the Ministry of Health and State and Municipal Health Secretariats ${ }^{(10)}$.

Given the above, it is essential that nurses know the scientific evidence on the phenomenon of gender violence that permeates the lives of trans women, in order to exercise a practice that is coherent with their social and health needs. It is noteworthy that the acquisition or expansion of knowledge necessary for comprehensive health care for these women can contribute to the reduction of new situations of violence in health services and enable visibility through the debate on the theme in social and political spaces.

\section{OBJECTIVES}

To identify scientific evidence on gender violence perpetrated against trans women.

\section{METHODS}

\section{Ethical aspects}

As this is a review study, there was no need for approval by the Ethics Committee for Research with Human Beings.

\section{Study type}

This is a descriptive study, integrative literature review type, in which the following steps were followed: identification of the research problem; literature search; selection of data from primary studies, evaluation of primary studies; data analysis, synthesis and presentation of results ${ }^{(11)}$.

\section{Methodological procedure}

The guiding question was elaborated through the $\mathrm{PICo}^{(12)}$ strategy, in which: "P" (population) - trans women; "I" (phenomenon of interest) - gender violence (physical, psychological, sexual); "Co" (context) - violence. The use of the strategy generated the following question: What is the scientific evidence on gender violence perpetrated against trans women?

For this study, original articles were included, in Portuguese, English or Spanish, with no time frame. Duplicate articles were excluded, being counted once in the database with the highest number of publications; articles that did not distinguish in their results the type of gender violence against trans women; publications without scientific editing not indexed; and gray literature (thesis, dissertations, course completion papers, handouts, annals, ordinances, and ministerial publications).

\section{Data collection and organization}

Searches in the databases took place in June 2020, by two researchers, through the Portal de Periódicos CAPES, with access made available by the Federal University of Pernambuco (UFPE). They were: Online Medical Literature Analysis and Retrieval System (MEDLINE), Latin American and Caribbean Literature on Health Sciences (LILACS), PsycINFO, Web of Science, Cumulative 
Index to Nursing and Allied Health Literature (CINAHL), Scopus and the Embase.

To access the articles, a single search strategy was defined, adapted according to the specificities of each database, as seen in Chart 1. The strategy consisted of controlled descriptors: Health Sciences Descriptors (DeCS), Medical Subject Headings Section (MeSH) and its entry terms, separated by Boolean logic, with OR between synonyms and AND to direct searches.

The search strategy was formulated according to the PICo strategy (P AND I AND Co) in which: $\mathrm{P}$ - Transgender persons OR Transgenders OR Gender identity OR Transsexualism; I - Gender based Violence OR Aggression OR Sex offenses OR Rape; Co Violence OR Domestic Violence.

Chart 1 - Strategies generated using controlled descriptors, Recife, Pernambuco, Brazil, 2020

\begin{tabular}{|c|c|}
\hline Database & Strategy \\
\hline MEDLINE & $\begin{array}{l}\text { (((("transgender persons") OR transgenders) OR "gender } \\
\text { identity") OR transsexualism) AND (((("gender-based } \\
\text { violence") OR aggression) OR "sex offenses") OR rape) } \\
\text { AND ((violence OR "domestic violence") }\end{array}$ \\
\hline $\begin{array}{l}\text { Scopus } \\
\text { PsycINFO }\end{array}$ & $\begin{array}{l}\text { "transgender persons" OR transgenders OR "gender } \\
\text { identity" OR transsexualism AND "gender-based } \\
\text { violence" OR aggression OR "sex offenses" OR rape AND } \\
\text { violence OR "domestic violence" }\end{array}$ \\
\hline $\begin{array}{l}\text { Embase } \\
\text { CINAHL } \\
\text { Web of Science }\end{array}$ & $\begin{array}{l}\text { \#1"transgender persons" OR transgender OR "gender } \\
\text { identity" OR Transsexualism } \\
\text { \#2: "gender-based Violence" OR aggression OR "sex } \\
\text { offenses" OR rape } \\
\text { \#3: violence OR "domestic Violence" } \\
\text { strategy: } 1 \text { AND \#2 AND \#3 }\end{array}$ \\
\hline LILACS & $\begin{array}{l}\text { "transgender persons" OR"transgender persons" OR } \\
\text { "transgender persons" OR"transgender persons" } \\
\text { OR transgender OR"gender identity" OR"gender } \\
\text { identity" OR"gender identity" OR transsexuality OR } \\
\text { transsexuality OR Transsexualism AND"gender } \\
\text { violence" OR"violence of gender" OR"gender-based } \\
\text { Violence" OR aggression OR aggression OR aggression } \\
\text { OR "sexual offences" OR "sexual offences" OR"sex } \\
\text { offenses" OR rape OR rape OR rape AND violence } \\
\text { OR violence OR violence OR"domestic violence" OR" } \\
\text { domestic violence" OR"domestic violence" }\end{array}$ \\
\hline
\end{tabular}

\section{Data analysis}

The selection of primary articles occurred, initially, with the export of studies from the databases to the reference management software, Zotero, for the extraction of duplicates ${ }^{(13-14)}$. Then, in order to compose the table of articles included in this research, based on the eligibility criteria, it was decided to use the internet application Rayyan Qatar Computing Research Institute - Rayyan QCRI ${ }^{(15)}$. The selection of extracted studies was done by pairs; and, in the event of an impasse on the inclusion of articles, there was the participation of a third reviewer to establish a consensus.

The data extracted for the qualitative analysis of the articles were based on an elaborated and validated instrument ${ }^{(16)}$ and were compiled in a Microsoft Excel spreadsheet with the purpose of presenting the following items: title, author, year and country of publication, journal, level of evidence, objective and main results. The final selection of the sample resulted in 16 original articles.
The following classification of evidence levels was considered: Level I - systematic review or meta-analysis; Level II - randomized clinical trial; Level III - non-randomized clinical trial; Level IV - cohort study or case-control study; Level V - study resulting from systematic review, descriptive and qualitative study; Level $\mathrm{VI}$ - study derived from a single descriptive or qualitative study; Level VII - expert opinion ${ }^{(17)}$.

The articles that made up the final sample were read to identify the main elements on gender violence perpetrated against trans women. The results were validated by the research group with a view to a confrontation of theoretical knowledge, expertise, and solid experience of researchers regarding the type of analysis carried out in conjunction with the subject under study. The presentation and synthesis of the results were prepared following the flowchart model Preferred Reporting Items for Systematic Reviews and Meta-Analyses (PRISMA-2009) in Figure 1 and Chart $2^{(18)}$.

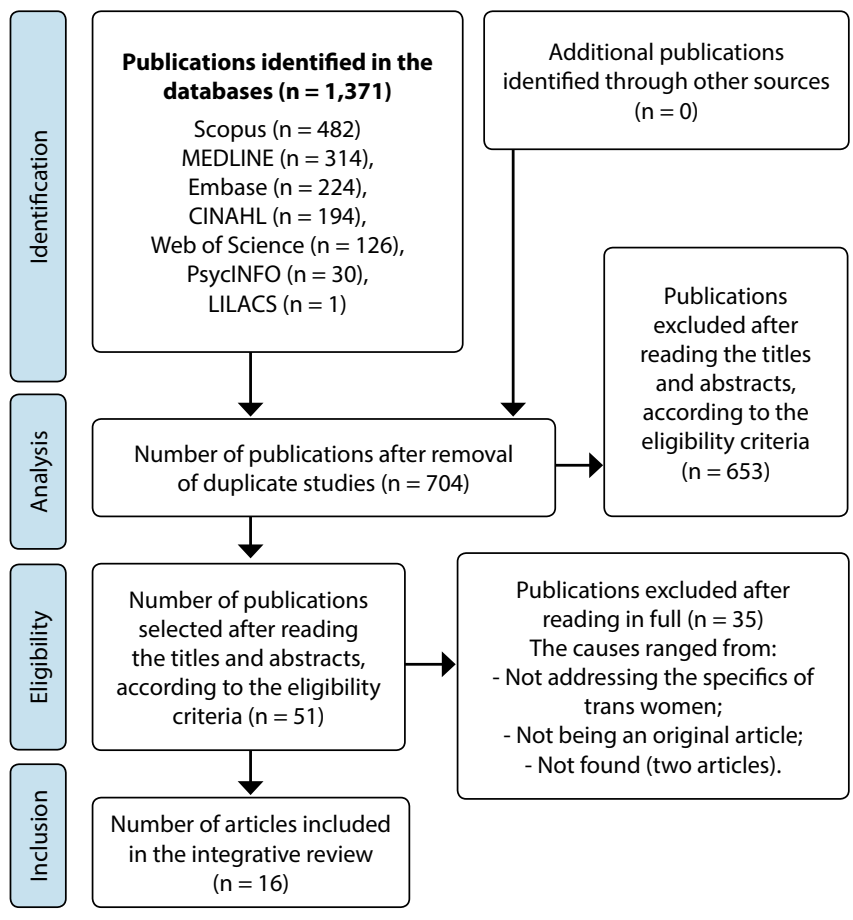

Figure 1 - PRISMA-2009 Flowchart for the selection of original articles included in the review, Recife, Pernambuco, Brazil, 2020

\section{RESULTS}

Regarding language, the 16 articles (100\%) were distributed in this way: 14 (87.5\%) in English; 1 (6.25\%) in Spanish; and 1 $(6.25 \%)$ in Portuguese. The countries that published the most were the United States of America (USA), 6 (37.5\%); Canada, 3 (18.75\%); Mexico, 3 (18.75\%); the others, Brazil, Colombia, Costa Rica, and Nepal, with 1 (6.25\%).

As for the institutions where the studies were carried out, those corresponding to the main author were registered, being ten $(62.5 \%)$ universities, three $(18.75 \%)$ institutions promoting health research, one (6.25\%) institution of research in several areas, one $(6.25 \%)$ institution linked to the prevention and combating of crimes and one (6.25\%) unidentified. 
The year with the most publications was 2019, with five articles (31.25\%), followed by 2016, 2017 and 2020 with two (12.5\%) articles each year; the other years, with one (6.25\%) article each; and one was published in 1995. The 16 articles found were published in 13 journals, of which 5 (38.46\%) were in the health area, 1 (7.69\%) was specifically in Nursing, and the others in the areas multidisciplinary: Social Work, Geography, Immigration and Violence. The levels of evidence identified were VI (81.25\%) and V (18.75\%), divided into mixed methods, descriptive or qualitative studies.

Gender violence perpetrated against trans women was addressed from different perspectives in the 16 (100\%) articles: HIV (25\%), social context (18.75\%), mental health (12.5\%), access to providers public services (12.5\%), immigration (12.5\%), penitentiary system (12.5\%), human rights (12.5\%), sex work (12.5\%) and intimate relationships (12.5\%), sometimes combining more than one perspective.

The most reported forms of violence were sexual (100\%); physics, in 12 articles (75\%); verbal, in 10 articles (62.5\%); psychological, in 8 (50\%); and financial, in 4 articles (25\%). One article presented only the sexual form of violence $(6.25 \%)$, while the others presented more than one.

As for the aggressors, police authorities were mentioned in six studies (37.5\%), professionals from health institutions, in three (18.75\%), in addition to: intimate partners (31.25\%); family members (43.75\%); friends or acquaintances (18.75\%); neighbors (12.5\%); and unknown (43.75\%). Offenders were not reported in two studies (12.5\%).

Chart 2 - Summary of articles included in the review, Recife, Pernambuco, Brazil, 2020

\begin{tabular}{|c|c|c|c|}
\hline $\begin{array}{l}\text { Authors / Year / } \\
\text { Country }\end{array}$ & Title & $\begin{array}{l}\text { Study design / } \\
\text { Level of evidence }\end{array}$ & Main results \\
\hline $\begin{array}{l}\text { Silva GWS, et al. }{ }^{(19)} \\
2016 \\
\text { Brazil }\end{array}$ & $\begin{array}{l}\text { Situations of violence against } \\
\text { transvestites and transsexuals } \\
\text { in a municipality in the Brazilian } \\
\text { Northeast }\end{array}$ & $\begin{array}{l}\text { Quantitative study } \\
\qquad \mathrm{VI}\end{array}$ & $\begin{array}{l}\text { Gender identity leads transsexual and transvestite women } \\
\text { to suffer verbal, physical, sexual violence, and neglect, } \\
\text { including in health services. }\end{array}$ \\
\hline $\begin{array}{l}\text { Dayton R, et al. } .^{(20)} \\
2020 \\
\text { USA }\end{array}$ & $\begin{array}{l}\text { Assessing an inclusive model to } \\
\text { increase access to comprehensive } \\
\text { gender-based violence response } \\
\text { services and improve HIV outcomes } \\
\text { in Puerto Plata, Dominican Republic }\end{array}$ & $\begin{array}{l}\text { Mixed methods } \\
\text { study } \\
\vee\end{array}$ & $\begin{array}{l}\text { Transsexual women are exposed to gender violence: physical, } \\
\text { psychological, sexual (often, the first sexual intercourse is } \\
\text { under duress and occurs in adolescence), torture, attempted } \\
\text { murder, professional or economic abuse. Gender violence } \\
\text { increases the risk of contracting HIV. }\end{array}$ \\
\hline $\begin{array}{l}\text { Salazar LF, et al. }{ }^{(21)} \\
2017 \\
\text { USA }\end{array}$ & $\begin{array}{l}\text { Contextual, experiential, and } \\
\text { behavioral risk factors associated } \\
\text { with HIV status: a descriptive } \\
\text { analysis of transgender women } \\
\text { residing in Atlanta, Georgia }\end{array}$ & $\begin{array}{l}\text { Qualitative study } \\
\text { VI }\end{array}$ & $\begin{array}{l}\text { Transsexual women often experience abuse that can begin } \\
\text { in childhood, in addition to intimate partner violence, } \\
\text { police maltreatment, prisons or sex work and are at a } \\
\text { greater chance of contracting HIV; and the same is true } \\
\text { for those who are unemployed, those who do not attend } \\
\text { schools and those who are homeless. }\end{array}$ \\
\hline $\begin{array}{l}\text { Kattari SK, et al. } 222) \\
2017 \\
\text { USA }\end{array}$ & $\begin{array}{l}\text { Differences in Experiences of } \\
\text { Discrimination in Accessing Social } \\
\text { Services Among Transgender/ } \\
\text { Gender Nonconforming Individuals } \\
\text { by (Dis)Ability }\end{array}$ & $\begin{array}{l}\text { Quantitative study } \\
\text { VI }\end{array}$ & $\begin{array}{l}\text { Transsexual women with or without special needs, exposed } \\
\text { to aggressions such as rape, severe intimate partner } \\
\text { violence, verbal abuse, and physical violence, when seeking } \\
\text { referral services for domestic and sexual violence, substance } \\
\text { abuse, mental health services, still suffer discrimination and } \\
\text { stigmatization, which worsen depending on factors such as } \\
\text { race, ethnicity, color, origin, education and special needs. }\end{array}$ \\
\hline $\begin{array}{l}\text { Anderson RE, et al. }{ }^{(23)} \\
2019 \\
\text { USA }\end{array}$ & $\begin{array}{l}\text { Differences in Rape } \\
\text { Acknowledgment and Mental } \\
\text { Health Outcomes Across } \\
\text { Transgender, Nonbinary, and } \\
\text { Cisgender Bisexual Youth }\end{array}$ & $\begin{array}{l}\text { Mixed methods } \\
\text { study } \\
\vee\end{array}$ & $\begin{array}{l}\text { Trans women who experience violence such as verbal } \\
\text { coercion, unwanted sexual contact and rape can suffer } \\
\text { several damages to their mental health, such as depression, } \\
\text { post-traumatic stress disorder and anxiety. }\end{array}$ \\
\hline $\begin{array}{l}\text { Swan LET, et al. } .^{(24)} \\
2019 \\
\text { USA }\end{array}$ & $\begin{array}{l}\text { Discrimination and Intimate } \\
\text { Partner Violence Victimization and } \\
\text { Perpetration Among a Convenience } \\
\text { Sample of LGBT Individuals in Latin } \\
\text { America }\end{array}$ & $\begin{array}{l}\text { Quantitative study } \\
\text { VI }\end{array}$ & $\begin{array}{l}\text { Intimate partner violence can involve trans women both } \\
\text { as a victim of verbal, psychological, physical, and sexual } \\
\text { aggression and as a perpetrator. }\end{array}$ \\
\hline $\begin{array}{l}\text { Rahil GJ, eta al. (25) } \\
2019 \\
\text { USA }\end{array}$ & $\begin{array}{l}\text { Experiences of sexual and gender } \\
\text { minorities in an urban enclave of } \\
\text { Haiti: despised, beaten, stoned, } \\
\text { stabbed, shot and raped }\end{array}$ & $\begin{array}{l}\text { Qualitative study } \\
\qquad \mathrm{VI}\end{array}$ & $\begin{array}{l}\text { Transsexual women are at risk of physical aggression, } \\
\text { humiliation, stoning, rape, gang rape and murder. The } \\
\text { hostile social context with several aggressors does not } \\
\text { allow them to react against aggression, which leads to the } \\
\text { potential risk of injuries and infection such as HIV; the latter } \\
\text { is still a potentiator of more stigma and various types of } \\
\text { violence, including institutional. }\end{array}$ \\
\hline $\begin{array}{l}\text { Namaste K. }{ }^{(26)} \\
1995 \\
\text { Canada }\end{array}$ & $\begin{array}{l}\text { Genderbashing: sexuality, gender, } \\
\text { and the regulation of public space }\end{array}$ & $\begin{array}{l}\text { Descriptive study } \\
\text { VI }\end{array}$ & $\begin{array}{l}\text { Trans women, even when adopting procedures or behaviors } \\
\text { that make them more feminine, such as surgeries, makeup, } \\
\text { and clothes, are still susceptible to verbal, physical and } \\
\text { sexual aggressions in public spaces due to their identity. } \\
\text { Furthermore, environments such as prisons are potential } \\
\text { places for rapes. }\end{array}$ \\
\hline
\end{tabular}




\begin{tabular}{|c|c|c|c|}
\hline $\begin{array}{l}\text { Authors / Year / } \\
\text { Country }\end{array}$ & Title & $\begin{array}{l}\text { Study design / } \\
\text { Level of evidence }\end{array}$ & Main results \\
\hline $\begin{array}{l}\text { Flores RL..(27) } \\
2016 \\
\text { Mexico }\end{array}$ & $\begin{array}{l}\text { HIV Prevalence Among Central } \\
\text { American Migrants in Transit Through } \\
\text { Mexico to the USA, 2009-2013 }\end{array}$ & $\begin{array}{l}\text { Quantitative study } \\
\text { VI }\end{array}$ & $\begin{array}{l}\text { Transsexual women in the migration process, in addition to } \\
\text { being exposed to sexual violence, still have increased risks } \\
\text { of contracting HIV because they cannot negotiate the use } \\
\text { of condoms. }\end{array}$ \\
\hline $\begin{array}{l}\text { Ritterbusch AE.(28) } \\
2015 \\
\text { Colombia }\end{array}$ & $\begin{array}{l}\text { Mobilities at Gunpoint: The } \\
\text { Geographies of (Im)mobility } \\
\text { of Transgender Sex Workers in } \\
\text { Colombia }\end{array}$ & $\begin{array}{l}\text { Qualitative study } \\
\qquad \text { VI }\end{array}$ & $\begin{array}{l}\text { In addition to being expelled from their families by paramilitary } \\
\text { groups, the exodus and establishment of trans women in other } \\
\text { cities are marked by police violence and situations of beatings, } \\
\text { rapes, verbal abuse, psychological violence, sex work and } \\
\text { stigmatization of their identities intertwined with HIV. }\end{array}$ \\
\hline $\begin{array}{l}\text { Krusi A, et al. }{ }^{(29)} \\
2018 \\
\text { Canada }\end{array}$ & $\begin{array}{l}\text { Positive sexuality: HIV disclosure, } \\
\text { gender, violence and the law - DA } \\
\text { qualitative study }\end{array}$ & $\begin{array}{l}\text { Qualitative study } \\
\qquad \mathrm{VI}\end{array}$ & $\begin{array}{l}\text { The double stigma due to the gender identity of trans } \\
\text { women and the presence of HIV contributes to them } \\
\text { becoming silent in the face of violence such as rape, not } \\
\text { getting the necessary help and experiencing more pain and } \\
\text { suffering in their lives. }\end{array}$ \\
\hline $\begin{array}{l}\text { Neisa ASP, Chavarría } \\
\text { DD. } .^{(30)} \\
2018 \\
\text { Costa Rica }\end{array}$ & $\begin{array}{l}\text { Progress and challenges in the } \\
\text { Costa Rican penitentiary system on } \\
\text { the specific needs of LGBTI persons } \\
\text { deprived of liberty }\end{array}$ & $\begin{array}{l}\text { Qualitative study } \\
\qquad \text { VI }\end{array}$ & $\begin{array}{l}\text { Transsexual women sometimes experience police abuse } \\
\text { because of their gender identity. And in prison institutions } \\
\text { it is no different, as some are subjected to abusive } \\
\text { approaches due to the stigma of transporting illicit objects } \\
\text { rectally, in addition to having to negotiate in exchange for } \\
\text { sexual favors or see sex work as the only source of income } \\
\text { in prison. }\end{array}$ \\
\hline $\begin{array}{l}\text { Wilson E, et al. }{ }^{(31)} \\
2011 \\
\text { Nepal }\end{array}$ & $\begin{array}{l}\text { Stigma and HIV risk among Metis } \\
\text { in Nepal }\end{array}$ & $\begin{array}{l}\text { Qualitative study } \\
\text { VI }\end{array}$ & $\begin{array}{l}\text { To escape from forced cultural marriages (as men), the } \\
\text { Metis, Nepali transsexual women, run away from home and } \\
\text { end up doing sex work to survive. In addition to all social } \\
\text { exposure to violence, police authorities do not protect } \\
\text { Metis' human rights and are also perpetrators of both sexual } \\
\text { violence and physical aggression and harassment. }\end{array}$ \\
\hline $\begin{array}{l}\text { Martínez DH-R.(32) } \\
2008 \\
\text { Mexico }\end{array}$ & $\begin{array}{l}\text { La otra migración: Historias de } \\
\text { discriminación de personas que } \\
\text { vivieron con VIH en México }\end{array}$ & $\begin{array}{l}\text { Qualitative study } \\
\text { VI }\end{array}$ & $\begin{array}{l}\text { Trans women in Mexico are under prejudice, violence, } \\
\text { and rejection from within the family. In addition to being } \\
\text { susceptible to verbal, physical, sexual violence, extortion, } \\
\text { rejection, and death, they do not find support even in the } \\
\text { health services, as well as, instead of being protected by the } \\
\text { police, they end up being more victimized by them. They } \\
\text { also face stigmatization when living with HIV. }\end{array}$ \\
\hline $\begin{array}{l}\text { Thompson LH. }{ }^{(33)} \\
2019 \\
\text { Canada }\end{array}$ & $\begin{array}{l}\text { Violence and Mental Health Among } \\
\text { Gender-Diverse Individuals Enrolled } \\
\text { in a Human Immunodeficiency Virus } \\
\text { Program in Karnataka, South India }\end{array}$ & $\begin{array}{l}\text { Quantitative study } \\
\text { VI }\end{array}$ & $\begin{array}{l}\text { Transsexual women in India are very susceptible to all } \\
\text { types of violence (physical, sexual, stigma, sex work), } \\
\text { including by family members and authorities, which ends } \\
\text { up being an impediment to seeking help and rights. This } \\
\text { leads to serious mental problems, such as low self-esteem, } \\
\text { lack of self-confidence, sleeping difficulties, depression, } \\
\text { and suicide. }\end{array}$ \\
\hline
\end{tabular}

\section{DISCUSSION}

Scientific evidence on gender-based violence perpetrated against trans women is presented in different forms and severities in different contexts ${ }^{(19-33)}$. It is essential to highlight that $78.8 \%$ of the murders of transgender and gender non-compliant people in the world occur in Latin America and the Caribbean, being derived from gender violence and transphobia that oppresses and makes abject the lives that affront the gender normativity ${ }^{(34)}$. Above all, the life expectancy of these people around the world stands out: 35 years old ${ }^{(34)}$.

Gender violence gives the person, in general the woman, the distorted image of less control and power over themselves in relation to a dominant figure, most of the time, male. The latter believes that they can even control the lives they judge to be inferior, which, in the condition of trans women, causes more exposure to social and health problems, such as HIV and other

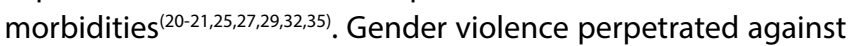
trans women is supported by female behavior and the expression of this woman's identity, permeating the psychological, verbal, physical, economic, sexual, family and labor fields, with a worsening of the context of exclusion and stigma ${ }^{(36)}$.

When trans women suffer rejections because of their gender identity, which can happen from childhood or adolescence, in the public or private sphere, there is the potential of marginalized contexts, the experience of educational evasion and precarious socioeconomic conditions ${ }^{(37)}$. Trans women with physical disabilities or some mental disorder, and who bring social markers such as race (black) and class (unfavorable socioeconomic condition), may be exposed to more violence, including perpetrated by reference services for people who have experienced sexual violence, psychological, domestic, chemical dependency, or mental illness. This highlights racism and social exclusion within care institutions ${ }^{(22,32)}$.

Trans women living with HIV may face a double stigma when seeking care in reference health institutions, regardless of their nationality. This situation occurs because they present a female gender identity and live with the virus, a condition that 
often results from sexual violence. Trans women seek services because they believe they can have treatment conducted under principles of confidentiality, privacy and dignity, but their serology is revealed, being the target of persecution and physical and symbolic violence ${ }^{(19-20,25,28-29,32)}$. Gender violence practiced in health services is a condition that drives trans women to neglected care, delaying basic treatments and enhancing health inequalities ${ }^{(34)}$.

Trans women can be inserted in a context of exposure to HIV closely linked to violence, which can accompany them from early adolescence and go through all stages of life. This exposure to the virus and other health problems can occur through forced sexual initiation and through family and social rejection of her identity, which drives her to sex work as a means of survival. The latter can also be the cause of more aggression and extortion from clients and/or ruffians ${ }^{(19-33,35)}$.

Exposure to HIV can also stem from assaults by strangers, sex with multiple partners, prison settings and even abuse by the police or other service providers. One can also add the context of illegal migration, in which the susceptibility to sexual violence is extreme, as well as the fear of being murdered during acts of violence, which prevents them from requesting the use of condoms and from seeking support legal and health ${ }^{(19-33,35)}$.

Non-consensual and unprotected sexual practices (oral and anal) permeate the lives of trans women in various scenarios, in an insertive or receptive way, regardless of sex work, as a way of affirming female inferiority and male control. They are usually accompanied by verbal aggression, intimidation, threats, beatings and extortion ${ }^{(25,35)}$.

The fear of retaliation when reporting situations of violence, or stigmatization and more violence when seeking support, silences trans women, producing suffering and mental and psychological illnesses such as depression, post-traumatic stress disorder, suicidal ideation, in addition to favoring greater exposure to sexually transmitted infections ${ }^{(23,33)}$.

Trans people are twice as likely to be assaulted throughout their lives compared to cisgender people, with special attention to sexual violence and violence by intimate partners; and have a $90 \%$ to $100 \%$ chance of experiencing traumatic events ${ }^{(38)}$. However, they can also experience the bidirectionality of violence in the relationship, in which they assume the role of perpetrators ${ }^{(24)}$. It is noteworthy that gender violence committed by intimate partners against trans women is aggravated by the abuse of alcohol and psychoactive substances. Among the most prevalent aggressions, psychological aggression is the most frequent, followed by physical aggression and sexual coercion ${ }^{(24)}$.

The fear of stigmatization, discrimination and discredit on the part of authorities when reporting intimate partner violence ${ }^{(37)}$ results in low demand for services in which nursing plays an important role in health promotion and in the prevention of injuries as a result of violence, such as HIV and other morbidities.

Many trans women are forced to leave their premises in their early adolescence due to factors such as discrimination, prejudice, rejection, physical and mental violence, abusive relationships committed by family members. In addition, they may flee home or cities because they face threats to their life and that of their family from groups of lawbreakers or gangs, or even to flee forced marriages, in which they would have to assume male roles to contribute the family economy ${ }^{(21,25-28,31,33)}$.

Sex work may appear as a means of survival, and it is possible for them to receive support from other trans women, however, this activity may be restricted by the police, due to gender identity; and they can also be victims of aggression from clients ${ }^{(21,25-28,31,33)}$. The more conditions for social exclusion that exist in the lives of trans women, such as poverty, racism and low education, the more frequent the violence ${ }^{(39)}$.

When trans women are in a situation of deprivation of liberty, they are placed in male penitentiaries and are susceptible to both aggressions from other people deprived of liberty and from employees of the institution ${ }^{(30)}$. In the context of deprivation of liberty, verbal attacks occur more frequently against trans women. Rape and sexual favors are also reported, as are blackmail and exploitation of sex work; in addition, their bodies are seen as transport for prohibited items, such as psychoactive substances and telephone devices, which makes them the target of more aggressive approaches by law enforcement authorities ${ }^{(30)}$.

Police approaches targeting trans women in countries such as Nepal, India, Colombia and Mexico have proven hostile and transgressive, with references to harassment, rape, beatings, threats, coercion, wrongful arrests and control over the displacement of these women ${ }^{(21,25-28,31,33)}$.

Trans women deprived of freedom, in general, have fragile support networks, which results in the difficulty to continue harmonization and to receive health care, favoring the maintenance of situations of violence ${ }^{(9)}$. However, many aggressions and ill-treatment are not reported due to the fear of retaliation and the weakened historical interaction with police authorities ${ }^{(39)}$, as already mentioned. Health care in this environment is focused on curative and urgent practice, which requires from the health professional a perceptive and discrimination-free look in order to identify the health needs of these women.

State representative institutions designed to protect and take care of the lives of the entire population present and maintain matrixes in gender binarism, with insufficient, unbalanced, and misguided actions to meet the needs of people outside this binary structure. This reveals that there is an urgent need to acquire knowledge and carry out training, especially in the health area, aimed at the specificities of trans women ${ }^{(40)}$.

Thus, the role of Nursing cannot be dispensed with in the search for knowledge with a focus on comprehensive care and health promotion for trans people, which should begin with the academic training of these professionals, even in educational institutions. In addition, it is necessary to strengthen the discussion through research, disease prevention actions, qualified listening, individual consultation, or emergency procedures. Trans women must be given emancipatory care, based on respect for life and free from negligence in all spheres of care ${ }^{(35)}$.

\section{Study limitation}

Studies that addressed conditions related to gender violence against trans women, in a non-specific way, associated with other gender identities and sexual orientations were not considered viable for this review, which may have limited the final sample. 


\section{Contributions to the field of nursing, health, or public policy}

Nursing (and other health sciences) must view gender violence as a public health problem and seek to understand the contexts involved in order to adopt actions based on urgent and mediated health needs arising from situations of violence against trans women. It is important that nurses acquire knowledge in the forensic area that is sufficient to collaborate in the search for justice and in the exclusionary social situations experienced by trans women, victims of physical and sexual violence ${ }^{(41)}$.

\section{CONCLUSIONS}

Scientific evidence suggests that gender violence that affects trans women is present globally and in different forms in various cultures. The faces of verbal, psychological, physical, and sexual gender violence perpetrated against trans women, practiced by family members, intimate partners, neighbors, police officers, health care providers, clients and strangers were identified. Trans women experience social exclusion and successive violence that result from stigma and discrimination due to their gender identity and that result in damage to health, which can even cause death.

Gender violence against trans women denotes a serious public health problem that needs to be visible in all spheres of society. Therefore, it is necessary that nurses and other health professionals, from the beginning of their training to their professional practice, know and discuss the gender violence perpetrated against them. The knowledge acquired, or expanded through continuing education, can provide health professionals with tools to collaborate in the fight against violence. This confrontation can take place through the construction of prevention and health promotion actions, which must occur in an interdisciplinary way in all care scenarios.

Finally, it is noteworthy that there is a need for research on the subject, especially empirical, in the context of Nursing, which aim to understand the mechanisms of social representation of trans women on gender violence, in order to promote an equitable and humanized practice.

\section{REFERENCES}

1. Connell R, Pearse R. Gênero: uma perspectiva global. 13 ed. São Paulo: Versos; 2015.

2. Flotskaya N, Bulanova S, Ponomareva M, Flotskiy N, Konopleva T. Gender Identity Development among Teenagers Living in the Subarctic Region of Russia. Behav Sci (Basel) 2018;8(10):90. https://doi.org/10.3390/bs8100090

3. Ring MEM. Transgénero, no es uma enfermidade. Rev Cub Salud Pública [Internet]. 2018 [cited 2020 Jun 17];45(4):e1540. Available from: http://scielo.sld.cu/pdf/rcsp/v45n4/1561-3127-rcsp-45-04-e1540.pdf

4. Caravaca-Morera JA, Bennington M, Williams C, Mackinnon K, Ross LE. Contemporalis homo sacer: barriers to accessing healthcare services for trans populations'. Texto Contexto Enferm. 2017;26(3):e3710016. https://doi.org/10.1590/0104-07072017003710016

5. Magno L, Dourado I, Silva LAV. Estigma e resistência entre travestis e mulheres transexuais em Salvador, Bahia, Brasil. Cad Saúde Pública. 2018;34(5):e00135917. https://doi.org/10.1590/0102-311x00135917

6. Brilhante AVM, Moreira GAR, Vieira LJES, Catrib AMF. A bibliometric study on gender violence. Saúde Soc. 2016;25(3):703-715. https://doi. org/10.1590/S0104-12902016148937

7. Leddy AM, Weiss E, Yam E, Pulerwitz J. Gender-based violence and engagement in biomedical HIV prevention, care and treatment: a scoping review. BMC Public Health. 2019;19:897. https://doi.org/10.1186/s12889-019-7192-4

8. Meneghel SN, Margarites AF. Feminicídio em Porto Alegre, Rio Grande do Sul, Brasil: iniquidades de gênero ao morrer. Cad Saúde Pública. 2017;33(12):e00168516. https://doi.org/10.1590/0102-311x00168516

9. United Nations. Discriminatory laws and practices and acts of violence against individuals based on their sexual orientation and gender identity. General Assembly [Internet]. Geneva: United Nations Human Rights Council; 2011 [cited 2020 Jun 18] Available from: https://www. ohchr.org/Documents/Issues/Discrimination/A.HRC.19.41_English.pdf

10. Ministério da Saúde (BR). Secretaria de Gestão Estratégica e Participativa. Departamento de Apoio à Gestão Participativa. Política Nacional de Saúde Integral de Lésbicas, Gays, Bissexuais, Travestis e Transexuais [Internet]. Brasília: Ministério da Saúde; 2013 [cited 2021 Feb 21]. Available from: https://bvsms.saude.gov.br/bvs/publicacoes/politica_nacional_saude_lesbicas_gays.pdf

11. Whittemore R, Knafl K. The integrative review: updated methodology. J Adv Nurs. 2005;52(5):546-53. https://doi.org/10.1111/j.1365-2648.2005.03621.x

12. Cardoso V, Trevisan I, Cicolella DA, Waterkemper R. Systematic review of mixed methods: method of research for the incorporation of evidence in nursing. Texto Contexto Enferm. 2019;28:e20170279. https://doi.org/10.1590/1980-265x-tce-2017-0279

13. Mendes KDS, Silveira RCCP, Galvão CM. Use of the bibliographic reference manager in the selection of primary studies in integrative reviews. Texto Contexto Enferm. 2019;28:e20170204. https://doi.org/10.1590/1980-265x-tce-2017-0204

14. Roy Rosenzweig Center for History. Zotero. George Mason University [Internet]. 2020 [cited 2020 Jun 15]. Available from: https://www.zotero.org/

15. Ouzzani M, Hammady H, Fedorowicz Z, Elmagarmid A. Rayyan: a web and mobile app for systematic reviews. Syst Rev. 2016;5:210. https:// doi.org/10.1186/s13643-016-0384-4

16. Ursi ES, Galvão CM. Prevenção de lesões de pele no perioperatório: revisão integrativa da literatura. Rev Latino-Am Enfermagem. 2006;14(1):124-31. https://doi.org/10.1590/S0104-11692006000100017 
17. Fineout-Overholt E, Melnyk BM, et al. Evidence-Based Practice Step by Step: Critical Appraisal of the Evidence: Part I. American Journal of Nursing. 2010; 110(7):47-52. https://doi.org/10.1097/01.NAJ.0000383935.22721.9c

18. Moher D, Liberati A, Tetzlaff J, Altman DG, The PRISMA Group. Principais itens para relatar Revisões sistemáticas e Meta-análises: a recomendação PRISMA. Epidemiol Serv Saúde. 2015;24(2):335-342. https://doi.org/10.5123/S1679-49742015000200017

19. Silva GWS, Souza EFL, Sena RCF, Moura IBL, Sobreira MVS, Miranda FAN. Cases of violence involving transvestites and transsexuals in a northeastern Brazilian city. Rev Gaúcha Enferm. 2016;37(2):e56407. https://doi.org/10.1590/1983-1447.2016.02.56407

20. Dayton R, Alvarez B, Morales GJ, Rojas Almonte J, Faccini M, Gomes B, et al. Assessing an inclusive model to increase access to comprehensive gender-based violence response services and improve HIV outcomes in Puerto Plata, Dominican Republic. Cult Health Sex. 2019;22(9):1001-17. https://doi.org/10.1080/13691058.2019.1647556

21. Salazar LF, Crosby RA, Jones J, Kota K, Hill B, Masyn KE. Contextual, experiential, and behavioral risk factors associated with HIV status: a descriptive analysis of transgender women residing in Atlanta, Georgia. Int J STD AIDS. 2017;28(11):1059-66. https://doi.org/10.1177/0956462416686722

22. Kattari SK, Walls NE, Speer SR. Differences in experiences of discrimination in accessing social services among transgender/gender nonconforming individuals by (Dis)Ability. J Soc Work Disabil Rehabil. 2017;16(2):116-40. https://doi.org/10.1080/1536710X.2017.1299661

23. Anderson RE, Tarasoff LA, VanKim N, Flanders C. Differences in Rape Acknowledgment and Mental Health Outcomes Across Transgender, Nonbinary, and Cisgender Bisexual Youth. J Interpers Violence. 2021;36(13-14):NP7717-NP7739. https://doi.org/10.1177/0886260519829763

24. Swan LET, Henry RS, Smith ER, Aguayo Arelis A, Rabago Barajas BV, Perrin PB. Discrimination and intimate partner violence victimization and perpetration among a convenience sample of LGBT Individuals in Latin America. J Interpers Violence. 2021;36(15-16):NP8520-NP8537. https://doi.org/10.1177/0886260519844774

25. Rahill GJ, Joshi M, Galea J, Ollis J. Experiences of sexual and gender minorities in an urban enclave of Haiti: despised, beaten, stoned, stabbed, shot and raped. Cult Health Sex. 2020;22(6):690-704. https://doi.org/10.1080/13691058.2019.1628305

26. Namaste K. Genderbashing: sexuality, gender, and the regulation of public space. Environ Plan Soc Space [Internet]. 1996 [cited 2020 Aug 14];14(2):221-40. Available from: https://chisineu.files.wordpress.com/2013/03/genderbashing1.pdf

27. Leyva-Flores R, Infante C, Gutierrez JP, Quintino-Perez F, Gómez-Saldivar M, Torres-Robles C. Migrants in transit through Mexico to the US: experiences with violence and related factors, 2009-2015. PLoS ONE. 2019;14(8):e0220775. https://doi.org/10.1371/journal.pone.0220775

28. Ritterbusch AE. Mobilities at gunpoint: the geographies of (im)mobility of transgender sex workers in Colombia. Ann Am Assoc Geogr. 2016;106(2):422-33. https://doi.org/10.1080/00045608.2015.1113112

29. Krüsi A, Ranville F, Gurney L, Lyons T, Shoveller J, Shannon K. Positive sexuality: HIV disclosure, gender, violence and the law: a qualitative study. PLoS ONE. 2018;13(8):e0202776. https://doi.org/10.1371/journal.pone.0202776

30. Pineda Neisa AS, Durán Chavarría D. Progress and challenges in the Costa Rican penitentiary system on the specific needs of LGBTI persons deprived of liberty. J Criminol Res Policy Pract. 2020;6(3):243-54. https://doi.org/10.1108/JCRPP-02-2020-0024

31. Wilson E, Pant SB, Comfort M, Ekstrand M. Stigma and HIV risk among Metis in Nepal. Cult Health Sex. 2011;13(3):253-66. https://doi.org/10. 1080/13691058.2010.524247

32. Martínez DH-R. The other migration: Histories of discrimination of people who lived with HIV in Mexico. Salud Ment [Internet]. 2008 [cited 2020 Aug 14];31(4):253-60. Available from: http://www.scielo.org.mx/pdf/sm/v31n4/v31n4a2.pdf

33. Thompson LH, Dutta S, Bhattacharjee P, Leung S, Bhowmik A, Prakash R, et al. Violence and mental health among gender-diverse individuals enrolled in a human immunodeficiency virus program in Karnataka, South India. Transgender Health. 2019;4(1):316-25. https://doi. org/10.1089/trgh.2018.0051

34. Malta M, Silva AB, LeGrand S, Whetten K, Wells S. HIV/AIDS, human rights, and transgender people in Latin America. Lancet Public Health. 2019;4(6):e279. https://doi.org/10.1016/S2468-2667(19)30082-9

35. Abreu PD, Araújo EC, Vasconcelos EMR, Moura JWS, Sousa JC, Santos CB. Transexual "womanhood" and the emergence of transfeminism: rhetorics of HIV/AIDS in the light of the queer theory. Texto Contexto Enferm. 2019;28:e20180294. https://doi. org/10.1590/1980-265X-TCE-2018-0294

36. Magno L, Dourado I, Silva LAV, Brignol S, Amorim L, MacCarthy S. Gender-based discrimination and unprotected receptive anal intercourse among transgender women in Brazil: A mixed methods study. PLoS ONE. 2018;13(4):e0194306. https://doi.org/10.1371/journal.pone.0194306

37. Divan V, Cortez C, Smelyanskaya M, Keatley J. Transgender social inclusion and equality: A pivotal path to development. J Int AIDS Soc. 2016;19. https://doi.org/10.7448/IAS.19.3.20803

38. Shipherd JC, Berke D, Livingston NA. Trauma recovery in the transgender and gender diverse community: extensions of the minority stress model for treatment planning. Cogn Behav Pract. 2019;26(4):629-46. https://doi.org/10.1016/j.cbpra.2019.06.001

39. Puckett JA, DuBois LZ, McNeill JN, Hanson C. The Association between Social Dominance Orientation, Critical Consciousness, and Gender Minority Stigma. J Homosex. 2020;67(8):1081-96. https://doi.org/10.1080/00918369.2019.1603493

40. Langenderfer-Magruder L, Walls NE, Kattari SK, Whitfield DL, Ramos D. Sexual victimization and subsequent police reporting by gender identity among lesbian, gay, bisexual, transgender, and queer adults. Violence Vict. 2016;31(2):320-31. https://doi.org/10.1891/0886-6708.VV-D-14-00082

41. Du Mont J, Kosa SD, Solomon S, Macdonald S. Assessment of nurses' competence to care for sexually assaulted trans persons: a survey of Ontario's Sexual Assault/Domestic Violence Treatment Centres. BMJ. 2019;9(5):e023880. https://doi.org/10.1136/bmjopen-2018-023880 